\title{
ВПЛИВ ЕКСПЕРИМЕНТАЛЬНОГО ГІПО- ТА ГІПЕРТИРОЗУ МАТЕРИНСЬКОГО ОРГАНІЗМУ НА ЛЕКТИНОВИЙ ПРОФІЛЬ НАДНИРКОВИХ ЗАЛОЗ ПОТОМСТВА
}

\begin{abstract}
Резюме. 3 використанням методів лектинової гістохімії проведено дослідження впливу експериментального гіпо- та гіпертирозу материнського організму на структурні компоненти надниркових залоз потомства на поступових етапах пре- і постнатального онтогенезу.

Мета дослідження - розширити спектр вивчених вуглеводних детермінант для отримання більш повного уявлення щодо зміни глікому надниркових залоз потомства, що розвивалося в умовах модельованої експериментальної патології.

Матеріали і методи. Гіпотироз моделювали шляхом щоденного згодовування самкам 10 мг/кг маси антитироїдного препарату “Мерказоліл", гіпертироз індукували згодовуванням L-тироксину в дозі 100 мкг/кг. Панель лектинів включала конканавалін A (Con A), лектини сочевиці (LCA), нарциса (NPA), арахісу (PNA), виноградного слимака (HPA), гриба грузлика димчастого (CNFA), зав'язків пшениці (WGA), бузини чорної (SNA), кори золотого дощу (LABA).

Результати досліджень та їх обговорення. Встановили, що морфогенез глікополімерів надниркових залоз щура в основному завершується до 10-ї постнатальної доби і проявляється накопиченням у мозковій речовині рецепторів лектинів LCA, PNA, CNFA, WGA, SNA та LABA. Гіпотироз материнського організму зумовлював затримку розвитку, вазодилатацію судин мозкової речовини, набряк паренхіми у поєднанні з лейкоцитарною інфільттрацією сітчастої зони та мозкової речовини, змінами глікому надниркових залоз потомства. Зміни рецепторів лектинів, індуковані гіпо- та гіпертирозом, загалом носили однонаправлений характер, що може бути спричинене негативним впливом обох патологічних станів на кінцеві етапи глікозилювання біополімерів у клітинах. Лектин WGA може бути рекомендований для диференційного виявлення епінесроцитів та норепінефроцитів, апоптосом у складі мозкової речовини; лектин PNA - для виявлення елементів комплексу Гольджі у складі адренокортикоцитів, секреторних гранул хромафінних клітин; лектини LCA та LABA - для виявлення комплексу Гольджі у складі хромафрінних клітин; лектини NPA та PNA - в якості маркерів активованих макрофрагів; лектини Con A та SNA - в якості маркерів еозиносрільних гранулоцитів крові, які на тлі гіпотирозу інфільтрували строму надниркових залоз.

Висновки. Проведене дослідження продемонструвало суттєвий вплив дисбалансу тироїдних гормонів материнського організму на морфогенез, мікроморфологію та вуглеводні детермінанти надниркових залоз потомства, причому гіпотироз індукував більш виражені зміни порівняно з гіпертирозом. Отримані дані щодо можливостей селективного маркування лектинами структурних компонентів надниркових залоз щура можуть бути корисними для моніторингу фізіологічних і патологічних процесів у цих органах.
\end{abstract}

Ключові слова: щури; онтогенез; надниркові залози; щитоподібна залоза; материнський гіпо- та гіпертироз.

ВСтУп Порушення фрункції щитоподібної залози належать до найпоширеніших захворювань, охоплюючи близько 3 \% населення світу [1]. Численні спостереження свідчать про вагомий вплив тироїдних гормонів на розвиток і фрункціонування надниркових залоз - як безпосередньо, так і через гіпоталамо-гіпофрізарно-адреналову вісь [2]. Гормони щитоподібної і надниркових залоз відіграють ключову роль у забезпеченні внутрішньоматкового гомеостазу, дисреренціації і дозріванні органів плода відповідно до часу гестації [3].

Результати аналізу доступної літератури показали відсутність публікацій, які б характеризували зміни глікокон'югатів структурних компонентів надниркових залоз потомства, що розвивалися за умов гіпо- чи гіпертирозу материнського організму, хоча відомо, що гліком клітин відіграє важливу роль у реалізації фрундаментальних процесів життєдіяльності, забезпечуючи взаєморозпізнавання та взаємодію клітин з їхнім мікрооточенням [4]. В арсеналі сучасних інструментів дослідження глікокоду живих організмів вагоме місце належить методам лектинової гістохімії [5-7]. Володіючи унікальною властивістю вибірково зв'язуватися 3 вуглеводними детермінантами клітин та міжклітинного матриксу, лектини дозволяють отримати достовірну інформацію щодо їхньої гістотопографії, перебудови при реалізації процесів ембріогенезу, в динаміці фрізіологічних відправлень та розвитку різноманітних фрорм патології [8-10].

У попередніх дослідженнях [11, 12] ми показали вплив експериментального гіпо- та гіпертирозу материнського організму на гістотопографрію рецепторів лектинів зарод- ків пшениці (WGA) та арахісу (PNA) у надниркових залозах потомства.

Метою дослідження було розширити спектр вивчених вуглеводних детермінант для отримання більш повного уявлення щодо зміни глікому надниркових залоз потомства, що розвивалося в умовах модельованої експериментальної патології.

МАТЕРІАЛИ I МЕТОДИ Дослід проводили на 40 самках щурів лінії Вістар масою 180-200 г, яких поділили на 3 групи: перша - контрольна (10), друга - 3 індукованим гіпотирозом (15), третя - 3 гіпертирозом (15), від яких отримали потомство в кількості 113 особин. Експериментальний гіпотироз викликали згодовуванням самкам антитироїдного препарату “Мерказоліл” (“Здоров'я”, Харків) 3 розрахунку 10 мг/кг маси тіла. Гіпертироз індукували щоденним згодовуванням з їжею препарату "L-тироксин" ("Berlin-Chemie", Німеччина) у дозі 100 мкг/кг маси тіла. Мерказоліл та L-тироксин додавали в їжу у вигляді порошку щоденно протягом 2-х тижнів до початку вагітності, упродовж усього гестаційного періоду та лактації. Контроль фрункції щитоподібної залози здійснювали шляхом вивчення ії̈ морфології та радіоімунологічного визначення гормонів $\mathrm{T}_{3}$ та $\mathrm{T}_{4}$. Через два тижні від початку експерименту шляхом щоденного взяття мазків із піхви самок контролювали естральний цикл. Самок у стадії еструсу підсаджували до інтактних самців. Перший день вагітності визначали за наявністю сперматозоїдів у піхвових мазках. Під час роботи з тваринами керувались Загальними етичними принципами експериментів на тваринах (Україна, 2001), узгодженими з вимогами Європейської конвенції про захист хребетних тварин, що ви- 
користовуються в експериментальних та інших наукових цілей» (Страсбург, 1986), Законом України № 3447-IV від 21.02.2006 "Про захист тварин від жорстокого поводження", Директиви Ради Європи 2010/63/EU, Гельсинською декларацією про гуманне ставлення до тварин.

Для ідентифікації глікокон'югатів використали панель із 9 лектинів, мічених пероксидазою хрону. Панель лектинів включала конканавалін A (Con A), лектини сочевиці (LCA), нарциса (NPA, усі специфічні до залишків DMan в олігосахаридних ланцюгах різних конфрігурацій), арахісу (PNA, специфічний до DGal(ß1-3)DGalNAc), виноградного слимака (HPA, специфічний до DGalNAc( $\alpha 1-3)$ DGalNAc), гриба грузлика димчастого (CNFA, специфічний до DGalNAc(B1-4)DGIcNAc), зав'язків пшениці (WGA, специфрічний до DGIcNAc > NeuNAc), бузини чорної (SNA, специфрічний до NeuNAc( $\alpha 2-6) \mathrm{DGal})$, кори золотого дощу

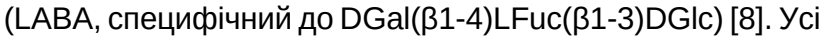
використані лектини, за винятком лектину арахісу, були виготовлені з сировини Карпатського регіону і кон'юговані 3 пероксидазою д. фрарм. наук, проф. В. О. Антонюком; кон'югат лектину арахісу (PNA) з пероксидазою виробництва форми "Sigma" (США).

Досліджуваний матеріал - щитоподібна та надниркові залози самок, надниркові залози їх потомства на 20-ту пренатальну; 1-шу, 10-ту, 40-ву доби постнатального розвитку забирали після евтаназії тварин шляхом передозування діетилесрірного наркозу. Відібраний матеріал фріксували в суміші Буена і заливали у парафін за загальноприйнятою методикою. Обробку зрізів лектинами та візуалізацію їхніх рецепторів діамінобензидином, а також контроль специорічності гістохімічних реакцій здійснювали як описано раніше $[11,12]$. Огляд та фротографування гістологічних препаратів здійснювали за допомогою мікроскопа "Granum", обладнаним камерою "Echoo-Imager 502 000" з використанням програми ToupView 3.7.

РЕЗУЛЬТАТИ ДОСЛІДЖЕНЬ ТА ЇХ ОБГОВОРЕННЯ Найвагоміші зміни глікому структурних компонентів надниркових залоз як у процесі їхнього морфогенезу, так і на тлі модельованої тироїдної патології, були отримані 3 використаням лектинів LCA, NPA, PNA, CNFA, WGA, разом з тим, як зміни рецепторів Con A, HPA, SNA, LABA носили менш виражений характер. Так, на 20-ту добу пренатального онтогенезу в тварин контрольної групи

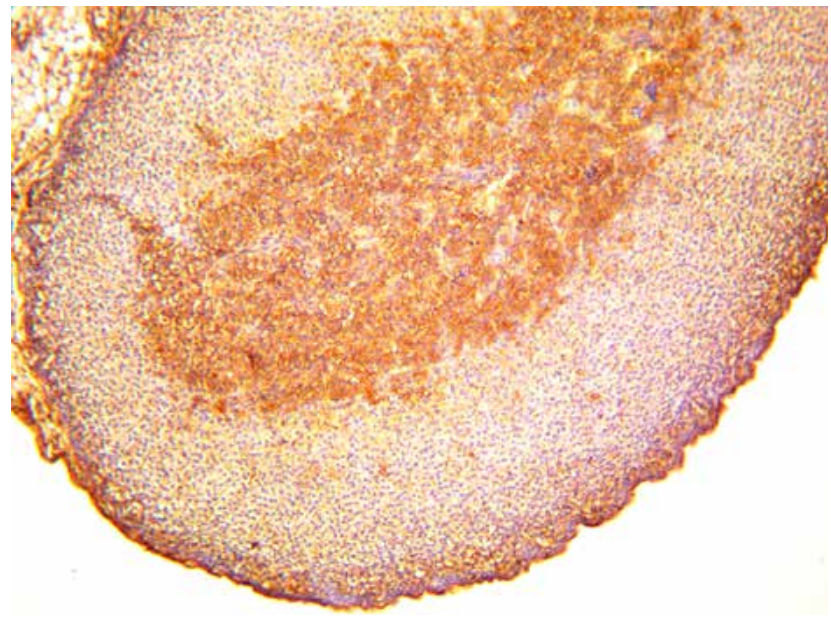

A лектини LCA та PNA інтенсивно маркували судини мікроциркуляторного русла, які чітко вирізнялися на тлі слабореактивної паренхіми надниркової залози. У центральних ділянках органа з використанням лектинів PNA, CNFA та WGA виявлено поодинокі острівці дрібних клітин із гетерохроматинізованими ядрами і світлою цитоплазмою, правдоподібно, попередники хромафріноцитів мозкової речовини. Використання лектинів забезпечило більш чітке виявлення означених клітин порівняно із забарвленням гематоксиліном й еозином. Подібне селективне маркування лектином PNA клітин мозкової речовини надниркових залоз миші було задокументовано M. Ahi et al. [13], починаючи з 19-ї доби пренатального онтогенезу.

У потомства, яке розвивалося за умов гіпотирозу материнського організму, спостерігали вазодилатацію судинного русла у поєднанні з відсутністю острівців хромафріноцитів, підвищення реактивності цитоплазматичних глікокон'югатів адренокортикоцитів з лектином PNA - визнаним маркером ембріональних та пухлинних клітин. Обидві ознаки свідчать про індуковану гіпотирозом затримку дозрівання органа, що узгоджується 3 даними Е. С. Детюк та співавт. [14], які отримали з використанням інших морфологічних методів. На тлі гіпотирозу було також задокументовано накопичення у цитоплазмі адренокортикоцитів рецепторів лектинів HPA, NPA та LABA. Гіпертироз, навпаки, індукував пришвидшення розвитку мозкової речовини, накопичення рецепторів лектину LABA у поєднанні з редукцією рецепторів лектинів NPA та SNA.

На 1-шу постнатальну добу з використанням лектинів LCA, HPA,WGA та SNA як в нормі, так і при гіпотирозі, у центральній частині надниркової залози виявлено острівці хромафінних клітин в оточенні адренокортикоцитів. Окрім того, високу афрінність з усіма використаними лектинами виявляли компоненти сполучнотканинної капсули надниркової залози, особливо колагенові волокна. На 10-ту постнатальну добу та більш пізніх етапах постнатального морфогенезу мозкова речовина була чітко відмежована від кори, хромафінні клітини демонстрували інтенсивне експонування рецепторів лектинів LCA, PNA, CNFA, WGA, SNA, LABA (рис. 1), що з одного боку свідчить про набуття наднирковими залозами щура дефінітивних ознак, а з іншого - про важливу роль глікополімерів у гістофрізіології хромафріноцитів.

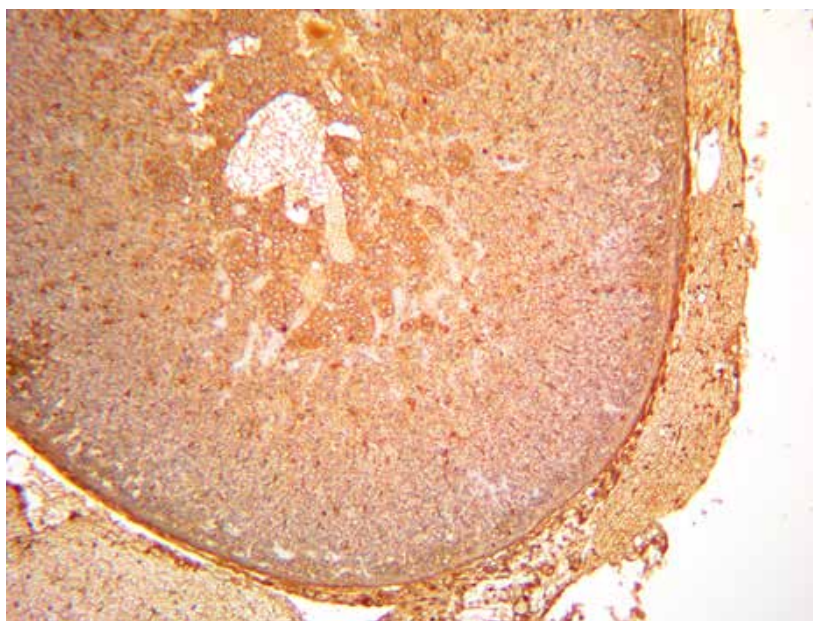
6

Рис. 1. Надниркові залози на 10-ту добу постнатального розвитку: А - норма: підвищена реактивність хромафіноцитів мозкової речовини; Б - значне розширення кровоносних судин мозкової речовини на тлі материнського гіпотирозу. Обробка лектином СNFA. х140. 
На тлі гіпотирозу в складі сітчастої зони, на межі кіркової та мозкової речовини виявлялися поодинокі клітини - правдоподібно активовані макрофраги, які інтенсивно взаємодіяли з лектинами NPA та PNA (рис. 2, 3A, 6A). 3 огляду на дані літератури [15] щодо фрункціональної спеціалізації окремих зон кори надниркових залоз щура, а саме трансформації фретальної кори у сітчасту зону 3 присутністю в останній резидентних макрофагів, ми виявили закономірності, які можна трактувати як наслідок підвищеної проліферативної активності клітин пучкової зони у поєднанні з посиленням в ній процесів апоптозу 3 наступною реутилізацією зруйнованих адренокортикоцитів макрофрагами сітчастої зони.

На 40-ву постнатальну добу в складі мозкової речовини надниркових залоз із використанням лектинів PNA, WGA та LABA ідентифріковано 2 субпопуляції хромафіноцитів (рис. 4A, 6А, 7A), що може бути пов'язано як 3 диференціацією епінефроцитів та норепінефроцитів, так і з різними фразами секреторного циклу, в яких перебували вищеозначені клітини. Окрім того, у складі мозкової речовини ідентисріковані дрібні клітини з інтенсивною реактивністю цитоплазми - ймовірно, хромафіноцити на різних стадіях апоптозу. Лектин PNA селективно взаємодіяв з елементами комплексу Гольджі адренокортикоцитів (рис. 5), а також 3 цитоплазматичною зернистістю хромасрінних клітин (рис. 6Б); лектини LCA та LABA - з елементами комплексу Гольджі хромафрінних клітин.

На тлі гіпотирозу материнського організму в складі сітчастої зони і мозкової речовини надниркових залоз потомства з використанням лектинів Con A та SNA було виявлено масивну еозинофрільну інфільтрацію (рис. ЗБ, 4Б). Це спостереження узгоджується з описаним Є. А. Согомонян та співавт. [16] феноменом інфільтрації цими клітинними елементами строми ендометрія щурів за умов гіпотирозу і відсутності аналогічної реакції на тлі гіпертирозу.

Відмінності у зв'язуванні лектинів структурами надниркової залози, зумовлені тироїдним дисбалансом, поступово нівелювалися до 40-ї доби постнатального

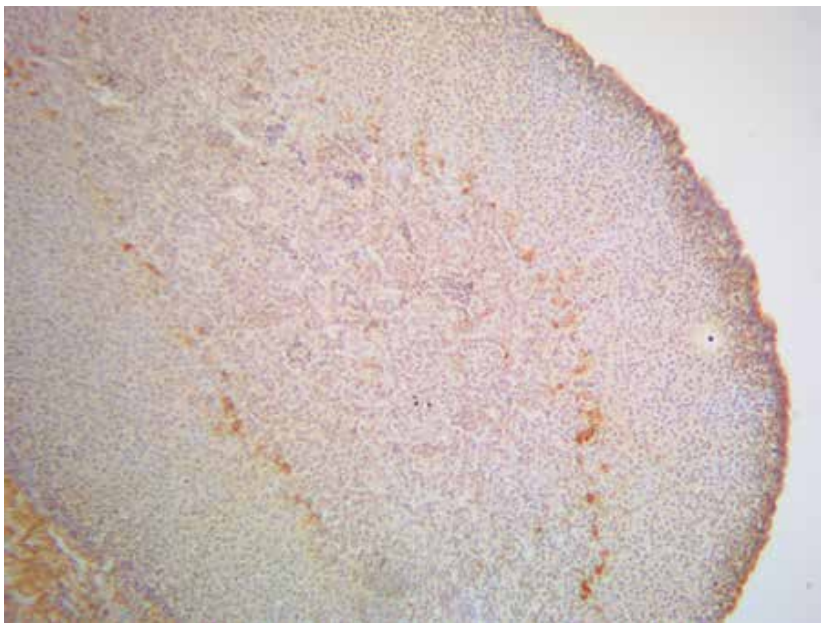

A розвитку - у зв'язку з переходом потомства на самостійне харчування, однак набували більш вираженої маніфестації у статевозрілих щурів із мерказоліліндукованим гіпотирозом. Так, в останніх було виявлено підвищення реактивності як кіркової, так і мозкової речовин з лектинами Con A, LCA, NPA, WGA у поєднанні зі зниженням вмісту рецепторів HPA і PNA. У складі комплексу Гольджі хромафіноцитів цієї дослідної групи підвищувалося експонуванням рецепторів LABA та LCA.

Розвиток потомства за умов гіпертирозу материнського організму індукував редукцію рецепторів лектину PNA у цитоплазмі хромафіноцитів, що може свідчити як про пришвидшення процесів морфогенезу, так і про певні порушення метаболізму цих клітин, зокрема порушення процесів кінцевого глікозування біополімерів, або пришвидшення їхньої секреції. Подібний феномен біологічно активних речовин на тлі експериментального гіпертирозу було описано раніше у слинних залозах щура [17]. Підвищення рівня секреції кортикостероїдів клітинами кори надниркових залоз у відповідь на стимуляторний вплив тироксину також задокументували E. O. Johnson et al. [18].

У результаті проведених досліджень було виявлено наступні можливості використання лектинів як селективних гістохімічних маркерів окремих типів і субпопуляцій клітин, елементів екстрацелюлярного матриксу надниркових залоз щура: (1) лектинів LCA, PNA, CNFA, WGA, SNA, LABA - в якості маркерів клітин мозкової речовини; (2) лектину WGA - для диференційного виявлення епінефроцитів та норепінефроцитів, апоптосом у складі мозкової речовини; (3) лектину PNA - для виявлення комплексу Гольджі у складі адренокортикоцитів, секреторних гранул хромафрінних клітин; (4) лектинів LCA та LABA - для виявлення комплексу Гольджі у складі хромафрінних клітин; (5) лектинів NPA та PNA - в якості маркерів активованих макрофрагів; (6) лектинів Con A та SNA - в якості маркерів еозинофільних гранулоцитів крові, які на тлі гіпотирозу інфрільтрували паренхіму надниркових залоз.

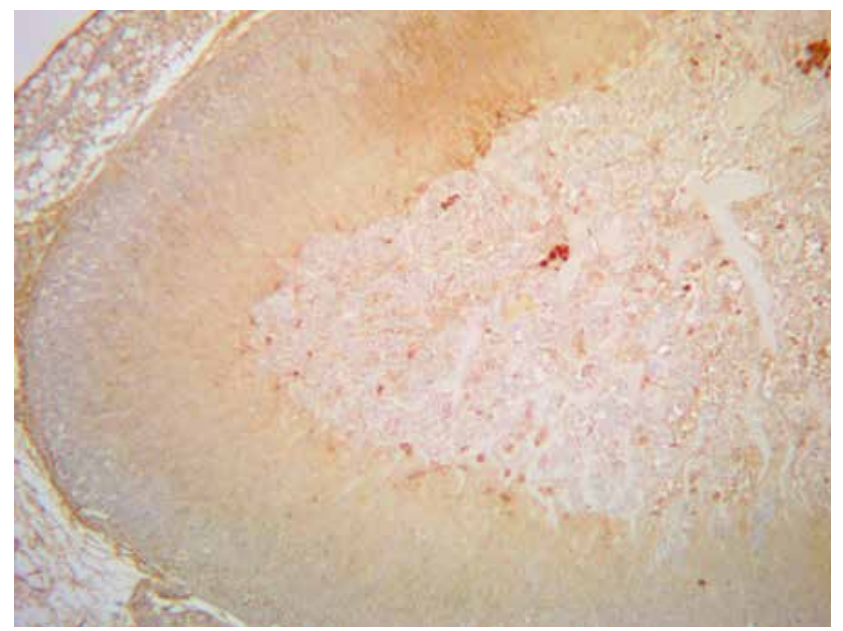

Б

Рис. 2. Надниркові залози на 10-ту добу постнатального онтогенезу: А - норма; Б - гіпотироз: на межі кіркової і мозковї речовини та у складі останньої - інтенсивно забарвлені активовані макрофраги; підвищена реактивність адренокортикоцитів пучкової і сітчастої зон. Обробка лектином NPA. х140. 


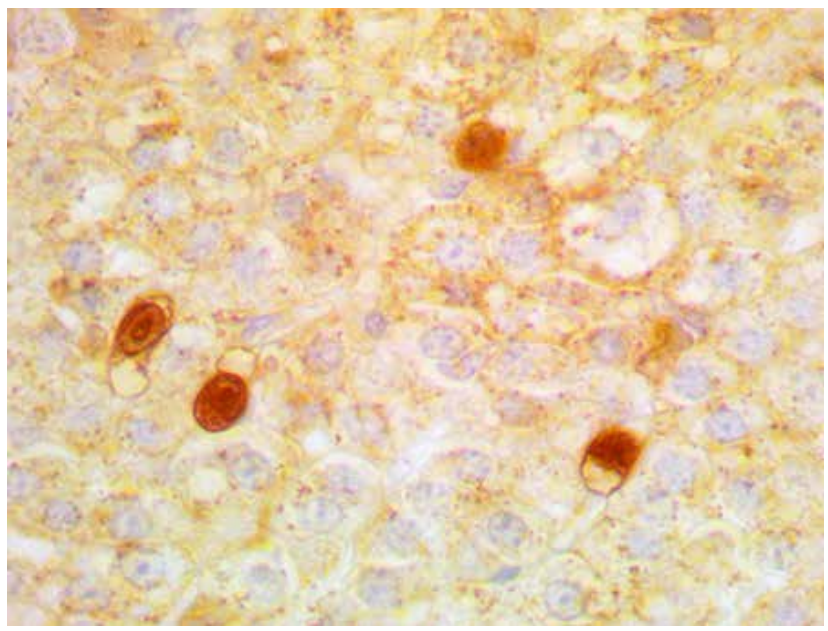

A

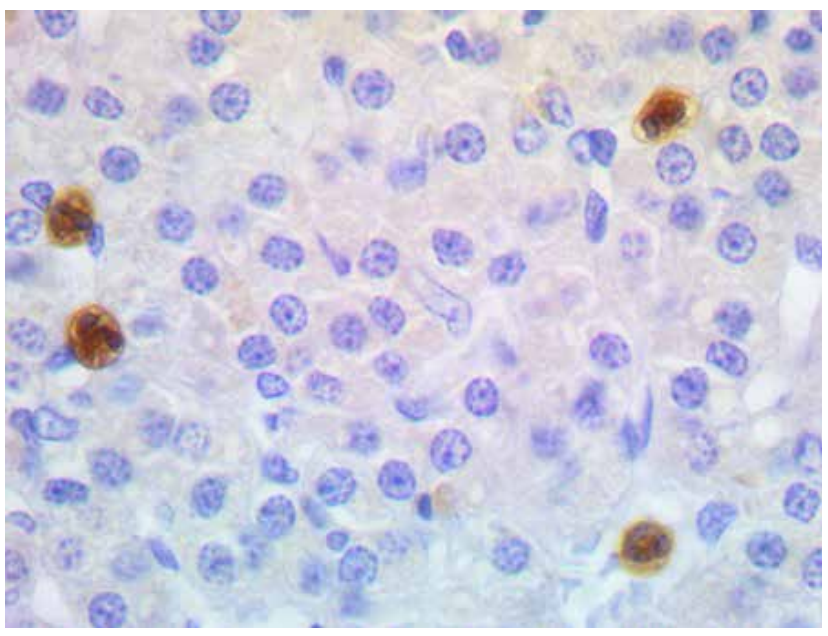

Б

Рис. 3. Гіпотирозіндуковане накопичення імуноцитів у паренхімі надниркової залози: А - активовані макрофраги у складі сітчастої зони, виявлені лектином NPA; Б - лейкоцитарна інфільтрація кіркової речовини, виявлена лектином Con A. x1400.

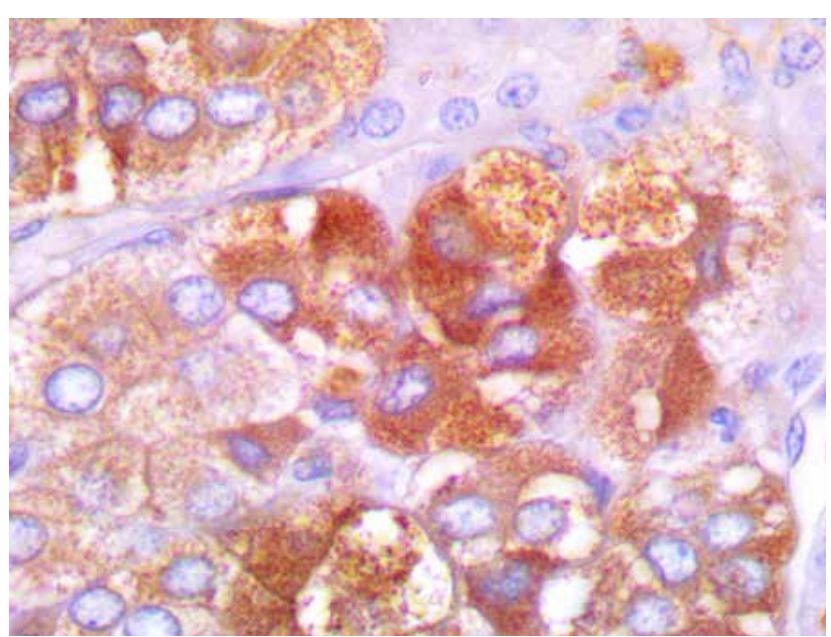

A

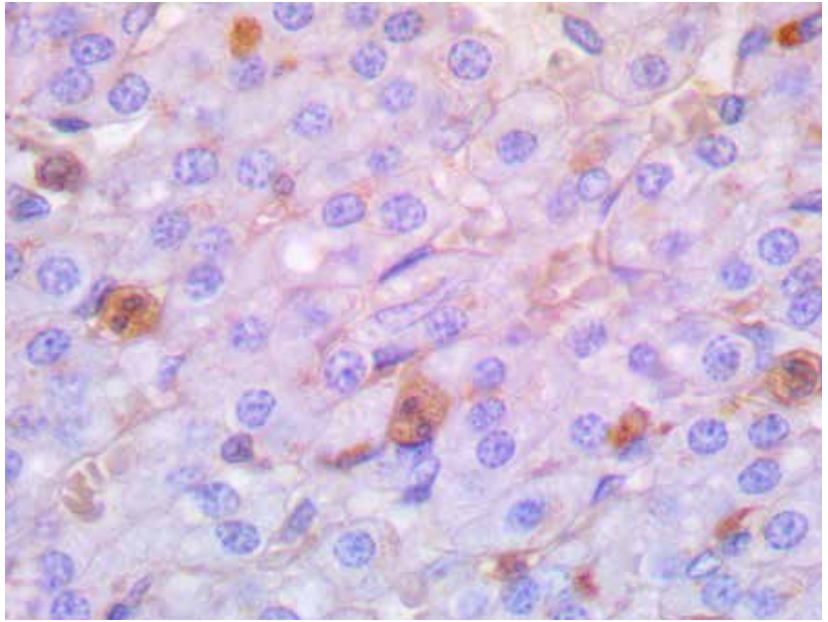

Б

Рис. 4. Селективне маркування структурних компонентів надниркових залоз щурят гіпотирозної групи на 40-ву постнатальну добу: А ретенція секреторних гранул хромафіноцитів, виявлена з використанням лектину LABA; Б - еозинофрільна інфрільтрація сітчастої зони, виявлена при обробці лектином SNA. x1400.

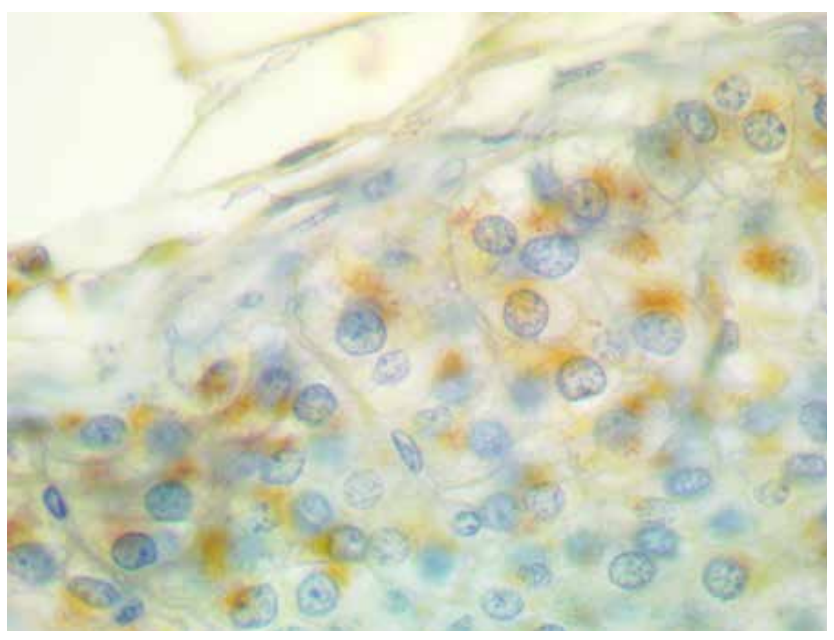

A

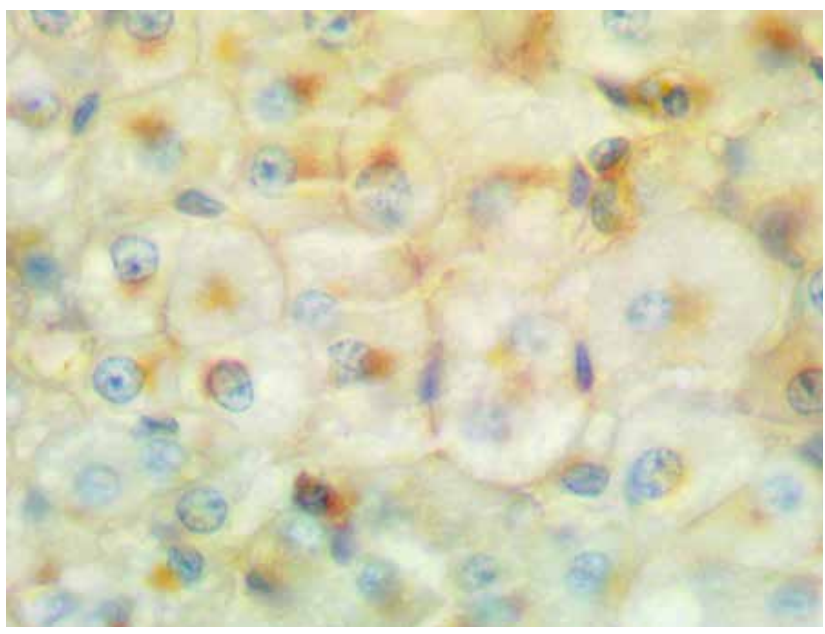

6

Рис. 5. Селективне виявлення комплексу Гольджі у складі адренокортикоцитів клубочкової (А) та пучкової (Б) зон надниркових залоз щурят гіпотирозної групи на 40-ву постнатальну добу розвитку з використанням лектину PNA. x1400. 


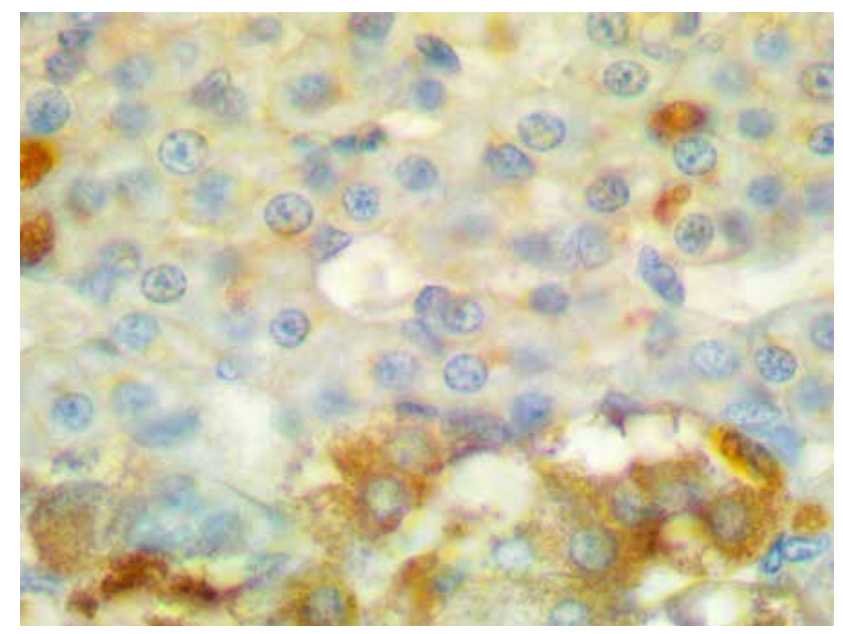

A

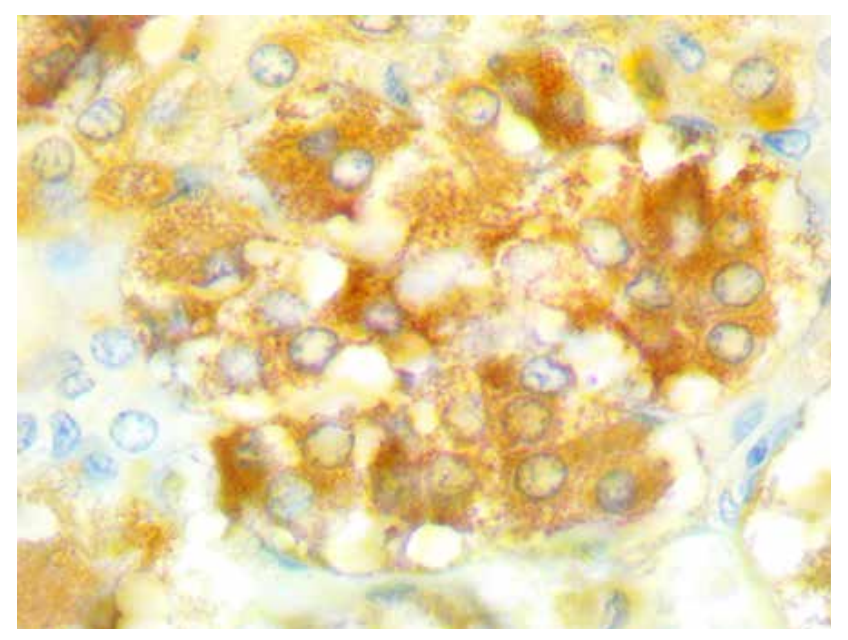

Б

Рис. 6. Зв'язування лектину РNA структурними компонентами надниркових залоз щурят, що розвивалися за умов гіпотирозу, на 40-ву добу постнатального онтогенезу: А - активовані макрофраги у складі пучкової зони; Б - субпопуляції хромафріноцитів у складі мозкової речовини. $\mathrm{x} 1400$.

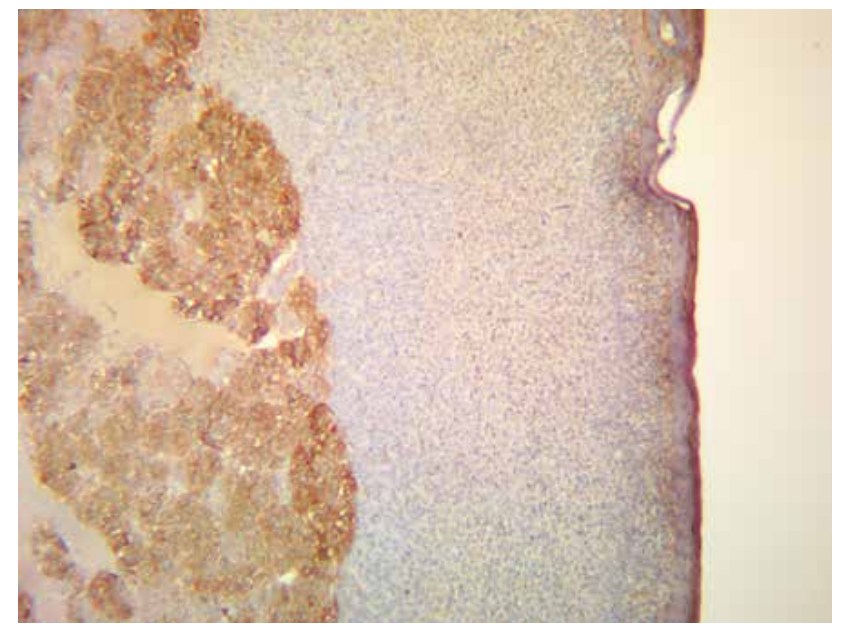

A

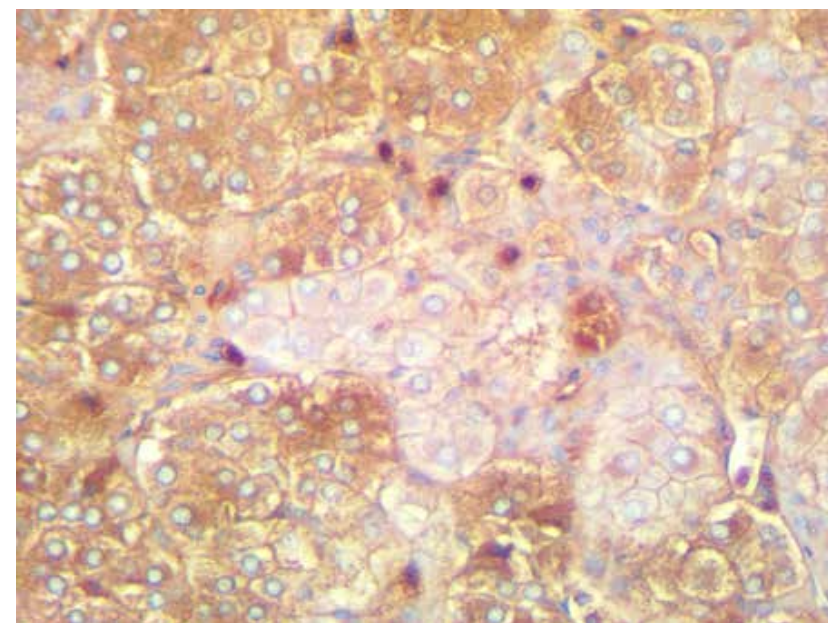

6

Рис. 7. Гістотопографрія рецепторів лектину WGA у наднирковій залозі статевозрілого щура контрольної групи: А - вибіркова реактивність мозкової речовини. х140; Б - три субпопуляції клітин у складі мозкової речовини: епінефроцити, норепінефроцити, апоптозні тільця (апоптосоми). х560.

ВИСНОВКИ 1. Використання лектинів продемонструвало якісні зміни вуглеводних детермінант структурних компонентів надниркових залоз щура як упродовж фрізіологічного морфогенезу, так і за умов гіпо- та гіпертирозу материнського організму. Отримані дані дозволяють стверджувати що становлення глікому надниркових залоз щура в основному завершується до 10-ї доби постнатального розвитку і супроводжується накопиченням у мозковій речовині рецепторів лектинів LCA, PNA, CNFA, WGA, SNA, LABA, що свідчить про важливу роль глікополімерів у гістофрізіології хромафріноцитів.

2. Гіпотироз індукував більш виражені зміни порівняно $з$ гіпертирозом, так гіпотироз материнського організму зумовлював затримку розвитку, вазодилатацію судин мозкової речовини, набряк паренхіми у поєднанні з лейкоцитарною інсрільтрацією сітчастої зони та мозкової речовини, зміну глікому надниркових залоз потомства. Зміни рецепторів лектинів, індуковані гіпо- та гіпертирозом, загалом носять однонаправлений характер, що може бути спричинене негативним впливом обох патологічних станів на кінцеві етапи глікозилювання біополімерів у клітинах.

3. Отримані дані щодо можливостей селективного маркування лектинами структурних компонентів надниркових залоз щура можуть бути корисними для моніторингу фрізіологічних і патологічних процесів у цих органах.

Перспективи подальших досліджень Провести імуногістохімічне виявлення маркерів проліферативної активності та явищ апоптозу в надниркових залозах щурів, вищеохарактеризованих експериментальних груп, i зіставити отримані дані з результатами лектинової гістохімії. 


\section{СПИСОК ЛІТЕРАТУРИ}

1. Паньків В. І. Практична тиреоїдологія / В. І. Паньків. - Донецьк : Заславський, 2011. - 224 с.

2. Yashchenko A. The influence of hypo- and hyperthyroidism on morphogenesis and histophysiology of adrenal glands / A. Yashchenko, S. Lutsyk // J. Embryol. Stem. Cell. Res. - 2018. - Vol. 2 (1). - P. 000107.

3. Chung H. R. Adrenal and thyroid function in the fetus and preterm infant / H. R. Chung // Korean J. Pediatr. - 2014. - Vol. 57 (10). - P. 425-433.

4. Gabius $H$. The sugar code: why glycans are so important / H. Gabius // Biosystems. - 2018. - Vol. 164. - P. 102-111.

5. Lectins. Methods and protocols. Methods in molecular biology 1200 / In: J. Hirabayashi ed. - New-York, Springer, 2014. - 614 p.

6. Histochemistry of single molecules. Methods and protocols. Methods in molecular biology / In: C. Pellicciari, M. Biggiogera eds. - Lectin histochemistry. Springer, 2017. - Vol. 1560. Part II. P. 93-147.

7. Roth J. Lectins for histochemical demonstration of glycans / J. Roth // Histochem. Cell. Biol. - 2011. - Vol. 136 (2). - P. 117-130.

8. Антонюк В. А. Лектини та їхні ресурси / В. А. Антонюк. Л. : Кварт, 2005. - 554 с.

9. Sharon N. Lectins. - 2-nd ed. / N. Sharon, H. Lis. - Dordrecht, Springer, 2007. $-464 \mathrm{p}$

10. Essentials of glycobiology. - 2-nd ed. / A. Varki, R. D. Cummings, J. D. Esko [et al.]. - Cold Spring Harbor, Cold Spring Harbor Laboratory Press; 2009. - P. 29-178.

11. Луцик С. А. Гістотопографрія сайтів WGA-рецепторів в постнатальному морфогенезі надниркових залоз щурів у фізіологічних умовах та при експериментальному гіпо- та гіпертиреозі материн- ського організму / С. А. Луцик, А. М. Ященко // Вісник проблем біології та медицини. - 2018. - Т. 2 (144). - С. 325-329.

12. Луцик С. А. Гістохімія і морфометричні характеристики лектину наднирників щурів, що розвиваються при гіпо- та гіпертиреозі матки / С. А. Луцик, І. Струс, А. М. Ященко // Морфологія. - 2018. - T. 12(2). - C. 30-39.

13. The role of GalNAc terminal sugar on adrenal gland development / M. Ahi, F. Zamansoltani, M. M. H. Taheri, A. R. E. Bideskan // Adv. Biol. Res. - 2007. - Vol. 1 (1-2). - P. 34-39.

14. Detiuk E. S. On the morphofunctional peculiarities of progeny adrenal glands developing under the influence of maternal hypothyroidism / E. S. Detiuk, M. S. Avgustinovich // Archiv of Anatomy, Histology and Embryology. - 1976. - Vol. 71 (10). - P. 41-45.

15. Atlas of histology of the juvenile rat / In: G. A. Parker, C. A. Picut eds. - Amsterdam: Elsevier-Academic Press, 2016. - P. 259-263; 275-291.

16. Sogomonian E. A. Histological structure and lectin receptor sites redistribution in endometrium of rats under experimental hypoand hyperthyroidism / E. A. Sogomonian, A. D. Lutsyk // Morphological Bulletin. - 2010. - Vol. 16 (3). - P. 558-564.

17. Луцик А. Д. Зв'язування лектинів з структурами підщелепної слинної залози щурів у постнатальному онтогенезі з патологією щитовидної залози / А. Д. Луцик, А. М. Ященко, Е. У. Детук // Архів анатомії, гістології та ембріології. - 1987. - Т. 92 (2). C. $40-48$.

18. Effects of experimentally induced hyperthyroidism on central hypothalamic-pituitary-adrenal axis function in rats: in vitro and in situ studies / E. O. Johnson, A. E. Calogero, M. Konstandi // Pituitary. - 2013. - Vol. 16 (2). - P. 275-286.

Отримано 02.10.18

Електронна адреса для листування: yashchenko_am@ukr.net

\section{INFLUENCE OF EXPERIMENTAL MATERNAL HYPO- AND HYPERTHYROIDISM ON THE LECTIN PROFILE OF PROGENY ADRENAL GLANDS}

Summary. By means of lectin histochemistry methods, the influence of experimental hypo- and hyperthyroidism of maternal organism on the structural components of progeny adrenal glands has been investigated on the successive stages of pre- and postnatal ontogenesis.

The aim of the study - to expand the spectrum of known carbohydrate determinants to obtain a more complete picture of glycemic adrenal gland changes that developed under conditions of simulated experimental pathology.

Material and Methods. Hypothyroidism was induced by daily feeding of female rats with $10 \mathrm{mg} / \mathrm{kg}$ of anti-thyroid drug Mercacolyl, and hyperthyroidism was induced by feeding L-thyroxine at a dose of $100 \mathrm{mkg} / \mathrm{kg}$. The lectin panel included concanavalin A (Con A), Lens culinaris agglutinin (LCA), Narcissus pseudonarcissus agglutinin (NPA), peanut agglutinin (PNA), Helix pomatia agglutinin (HPA), Clitocybe nebularis fungus agglutinin (CNFA), wheat germ agglutinin (WGA), Sambucus nigra agglutinin (SNA), Laburnum anagyroides bark agglutinin (LABA).

Results and Discussion. It was estimated that the morphogenesis of rat adrenal glands basically culminates on the 10th postnatal day and is manifested by the selective exposure of LCA, PNA, CNFA, WGA, SNA and LABA lectin receptor sites in the glandular medullary portion. Hypothyroidism of the maternal organism caused delayed maturation, dilation of medullary vasculature, swelling of the parenchyma in combination with leukocyte infiltration of zona reticularis and medullary portion, alterations in glycomic structure of progeny adrenal glands. Changes in the glycoreceptors induced by hypo- and hyperthyroidism were similar yet not identical, which may be due to the negative effect of both pathological conditions on the final steps of glycosylation. WGA can be used for differential detection of epinephrocytes and norepinephrocytes, apoptosomes in the adrenal gland medulla; PNA - for visualization of Golgi complex in within the adrenocorticocytes, and secretory granules of chromaffin cells; LCA and LABA - for the detection of Golgi complex in chromaffin cells; NPA and PNA - for selective labeling of activated macrophages; Con A and SNA - for labeling of migrant eosinophilic granulocytes, which under conditions of hypothyroidism? But not hyperthyroidism infiltrated stroma of the adrenal glands. Conclusions. Current study showed a significant impact of thyroid hormones imbalance within the maternal organism on morphogenesis, micromorphology, and carbohydrate determinants of progeny adrenal glands, with hypothyroidism inducing more pronounced changes in comparison with hyperthyroidism. The obtained data on the possibilities of selective marking by lectins of the rat adrenal glands structural components may be useful for monitoring of physiological and pathological processes in these same organs.

Key words: rats; ontogenesis; adrenal glands; thyroid gland; maternal hypo- and hyperthyroidism. 
ISSN 1681-276Х. ВІСНИК НАУКОВИХ ДОСЛІДЖЕНЬ. 2018. № 4

\section{ВЛИЯНИЕ ЭКСПЕРИМЕНТАЛЬНОГО ГИПО- И ГИПЕРТИРЕОЗА МАТЕРИНСКОГО ОРГАНИЗМА НА ЛЕКТИНОВЫЙ ПРОФИЛЬ НАДПОЧЕЧНИКОВ ПОТОМСТВА}

Резюме. С использованием методов лектиновой гистохимии исследовано влияние экспериментального гипо- и гипертироза материнского организма на структурные компоненты надпочечников потомства на последовательных этапах пре- и постнатального онтогенеза.

Цель исследования - расширить спектр известных углеводных детерминант для получения более полного представления об изменении гликома надпочечников потомства, развивавшегося в условиях моделируемой экспериментальной патологии. Материалы и методы. Гипотироз моделировали путем ежедневного скармливания самкам 10 мг/кг массы антитироидного препарата "Мерказолил", гипертироз индуцировали скармливанием L-тироксина в дозе 100 мкг/кг. Панель лектинов включала конканавалин A (Con A), лектины чечевицы (LCA), нарцисса (NPA), арахиса (PNA), виноградной улитки (HРA), гриба грузлика дымчатого (CNFA), зародышей пшеницы (WGA), бузины черной ( SNA), коры золотого дождя (LABA).

Результаты исследований и их обсуждение. Установили, что морфогенез надпочечников крысы в основном завершается к 10 суткам постнатального развития и проявляется избирательным накоплением в мозговом веществе рецепторов лектинов LCA, PNA, CNFA, WGA, SNA и LABA. Гипотироз материнского организма обуславливал задержку развития, вазодилатацию сосудов мозгового вещества, отек паренхимы в сочетании с лейкоцитарной инфильтрацией сетчатой зоны и мозгового вещества, изменениями гликома надпочечников потомства. Изменения рецепторов лектинов, индуцированные гипо- и гипертироз, носили однонаправленный характер, что может быть вызвано негативным влиянием обоих патологических состояний на конечные этапы гликозилирования биополимеров в клетках. Лектин WGA может быть рекомендован для дифференциального выявления эпинефроцитив и норэпинефроцитив, апоптосом в составе мозгового вещества; лектин РNА - для выявления элементов комплекса Гольджи в составе адренокортикоцитив, секреторных гранул хромаффинных клеток; лектины LCA и LABA - для выявления комплекса Гольджи в составе хромаффринных клеток; лектины NPA и PNA - в качестве маркеров активированных макрофрагов; лектины Con A и SNA - в качестве маркеров эозинофилов крови, которые на фроне гипотироза иноильтрировали строму надпочечников.

Выводы. Проведенное исследование продемонстрировало существенное влияние дисбаланса тиреоидных гормонов материнского организма на морфогенез, микроморфологию и углеводные детерминанты надпочечников потомства, причем гипотиреоз вызывал более выраженные изменения по сравнению с гипертирозом. Полученные данные относительно селективного маркирования лектинами структурных компонентов надпочечников крысы могут быть полезными для мониторинга фризиологических и патологических процессов в этих органах.

Ключевые слова: крысы; онтогенез; надпочечники; щитовидная железа; материнский гипо- и гипертироз. 